\title{
Utilization of Marginal Soils with Application of Phosphorus and Ethephon for Sweet Corn (Zea mays L. saccharata) cultivation
} Hartinee Abbas ${ }^{1}$, Zakaria Wahab ${ }^{2}$, Ayob Katimon ${ }^{3}$, Zaharah Abdul Rahman ${ }^{4}$

\author{
${ }^{1,3}$ School of Bioprocess Engineering, University Malaysia Perlis, Jejawi 3 Academic Complex, 02600 Arau, Perlis. \\ ${ }^{2}$ Faculty of Engineering Technology, University Malaysia Perlis, Uniciti Alam Campus, 02100 Sg. Chuchuh, Padang Besar, \\ Perlis. \\ ${ }^{4}$ Department of Land Management, University Putra Malaysia, 43400 Serdang, Selangor.
}

\begin{abstract}
Abundance of marginal soils is among the major constraint to achieve high yield for crop production due to unsuitable physical and chemical properties of the soils. Commonly, farmers would manage the marginal soil by adding soil amendment, compost and fertilizer which increase the cost of production. Alternatively, application of fertilizer together with plant growth regulator (PGR) during crop management can be practiced to utilize the marginal soil effectively. The aim of this experiment was to determine effects of phosphorus $(P)$ fertilizer and PGR namely ethephon on growth performance of sweet corn grown in three marginal soils namely Rasau, Kuah and Dampar. The treatments were arranged as factorial randomized complete block design with four rates of $P$ fertilizer and standard rate of ethephon replicated four times. The results indicated that the physical properties of the marginal soils vary which Rasau dan Kuah series have low content of silt (10.30\% and 36.10\%), respectively and clay (9.40\% and $11.86 \%)$ while Dampar series has low sand content (21\%). Consequently, Dampar series depicted highest soil moisture content (18.80\%) compared to Rasau and Kuah with high content of silt and clay at $42.43 \%$ and $36.43 \%$, respectively. At tasseling stage, where application of $P$ fertilizer with combination of ethephon at 0 and $15 \mathrm{~kg} \mathrm{P}_{2} \mathrm{O}_{5} \mathrm{ha}^{-1}$ there were significant difference between soil series on root length, total biomass wet and dry weight but exception for total biomass dry weight at $0 \mathrm{~kg}_{2} \mathrm{O}_{5} \mathrm{ha}^{-1}$. Moreover, at $45 \mathrm{~kg} \mathrm{P}_{2} \mathrm{O}_{5} \mathrm{ha}^{-1}$ there were significant difference among soil series on leaf number and total biomass dry weight whereas at highest $P$ rate of $60 \mathrm{~kg}$ $P_{2} O_{5} h^{-l}$ only root length and root volume were affected. Most of the results were observed highest on Rasau soil series which contain highest sand particle instead of silt and clay compared to Kuah and Dampar series. However, the addition of ethephon and several $P$ rates did not affect plant height among soil series. The results suggest that, the marginal soil can be utilized for sweet corn production by addition of combined $P$ fertilizer at low rate and PGR.
\end{abstract}

Keywords-Zea mays L. saccharata, marginal soil, phosphorus, ethephon, plant growth.

\section{INTRODUCTION}

Marginal soil for agriculture is characterized by soil which is poor in soil physical and chemical properties. These aspects play an important role for crop production in terms of growth performance and yield. The soil properties of each soil type may varies due to several factors such as parent material, topography, climate and agricultural practices. According to Shamsuddin and Markus (2008), most of the Malaysian soils are known as Oxisols, acidic in nature and developed from a range of parent materials which are dominated by kaolinite and oxides of iron $(\mathrm{Fe})$ and aluminium $(\mathrm{Al})$ (sesquioxides). The availability of $\mathrm{Al}$ and $\mathrm{Fe}$ in most acid soils would fixed soluble inorganic phosphorus (P) that subsequently affect availability of $\mathrm{P}$ for plant growth (Adnan et al., 2003). Yang et al. (2014) stated that $\mathrm{P}$ is an element essential for plant growth, fruit set, fruit development and fruit ripening and can be deficient or unavailable in agricultural soils.

As alternative, application of $\mathrm{P}$ fertilizers could overcome the problem so that the marginal soils can be used for cultivation and better yield production can be achieved. Furthermore, crop responses to fertilizer application are indirectly affected by soil physico-chemical properties where different soil texture will have diverse capability to hold plant nutrient. Application of P fertilizer in clay loam soil texture significantly increased dry matter yield, yield components and growth parameters of common bean (Taruko and Mohammed, 2014) whereas Wulan and Prijono (2013) in their study of different dry-land types concluded that factors influencing water infiltration are soil type, soil organic matter, porosity, bulk density, specific gravity and initial soil moisture content. Indeed, the proportion of sand, silt and clay in soil is so vital to the suitability of the soil for agriculture production in terms of water infiltration, soil moisture and nutrient retention.

Plant growth regulator namely ethephon (2-chloroethyl-phosphonic acid) is a systemic plant growth regulator that can be use directly either by soil drenching or foliar application to the plant. It will penetrate into plant tissue and decompose to ethylene, chloride ion and phosphonic acid (Bhat et al., 2010). At present, ethepon is widely used for specific function such 
as to hasten fruit ripening, stimulate flowering emergence and improve plant resistant to lodging. Ethephon treatment resulted in a significant reduction of corn plant height which was attributed to decrease in internode length (Mischeck and Fanuel, 2014). Moreover, ethephon will breakdown to release ethylene that will be involved to enhance root growth in soil with low nutrient concentration such as nitrogen, phosphorus and potassium (Postma and Lynch, 2011).

In order to utilize the marginal soils for crop production, proper crop and nutrient management should be adjusted according to the soil condition so that plant requirement will be sufficient to complete their cycle. Consequently, combined application of P fertilizer and ethephon to marginal soil would be a promising approach to improve crop growth performance. Therefore, the combined effect of ethephon and several rates of $\mathrm{P}$ application on growth performances of sweet corn (Zea mays $\mathrm{L}$. saccharata) grown in three marginal soils were investigated.

\section{MATERIALS AND METHODS}

The sampling area was located at Fruit Research Centre, Malaysian Agricultural Research and Development Institute (MARDI) Sintok, Kedah (6 $6^{\circ} 9^{\prime} 17.8^{\prime \prime}$ N, 100 $\left.29^{\prime} 00.8^{\prime \prime E}\right)$. The marginal soils series namely Rasau, Dampar and Kuah were collected at $0-20 \mathrm{~cm}$ by using stainless steel auger. The soil samples were air-dried before ground to pass through a $2.0 \mathrm{~mm}$ sieve. About $15 \mathrm{~kg}$ of each marginal soil were packed into a $40 \mathrm{~cm} \mathrm{x} 40 \mathrm{~cm}$ polybag before sweet corn hybrid (Leckat seed) at vegetative 2 stage (V2) were transplanted. The experiment was conducted in a factorial randomized complete block design (RCBD) with four replications. Four phosphorus (P) levels were 0, 15, 45 and $60 \mathrm{~kg} \mathrm{P}_{2} \mathrm{O}_{5}$ ha $^{-1}$ and standard recommendation of Ethephon at $270 \mathrm{ppm}$ was applied once to all treatments $(200 \mathrm{~mL}$ per polybag) by soil drench technique at critical vegetative stage development of sweet corn which was vegetative stage 5 (V5) or at 20 days after transplanting (Souza et al., 2016). The nitrogen (N) and potassium (K) were fixed at $120 \mathrm{~kg} \mathrm{~N} \mathrm{ha}^{-1}$ and $90 \mathrm{~kg} \mathrm{~K}_{2} \mathrm{O} \mathrm{ha}^{-1}$ for all treatments. Plant maintenance such as pest and diseases control followed standard procedure for sweet corn cultivation. Weed control was done manually when necessary. The seedlings were irrigated manually twice daily until field capacity level. The data collection was carried out during planting until tasseling (45 days after transplanting). Data of soil nutrient contents of the marginal soils were shown in Table 1 .

TABLE 1

THE NUTRIENT CONTENTS OF THE MARGINAL SOILS BEFORE THE EXPERIMENT AND METHODS USED FOR NUTRIENT DETERMINATION.

\begin{tabular}{|c|c|c|c|c|}
\hline \multirow[t]{2}{*}{ Soil properties } & \multicolumn{3}{|c|}{ Soil series } & \multirow[t]{2}{*}{ Method/Extractant } \\
\hline & Rasau & Kuah & Dampar & \\
\hline $\mathrm{pH}$ & 5.19 & 5.19 & 4.77 & Soil : water $1: 2.5$ \\
\hline Carbon $(\mathrm{C}), \%$ & 0.08 & 0.06 & 0.07 & Combustion TruMac CNS analyzer, LECO \\
\hline Nitrogen $(\mathrm{N}), \%$ & 0.67 & 0.77 & 0.73 & \\
\hline Phosphorus (P), $\mathrm{mg} \mathrm{kg}^{-1}$ & 45.22 & 71.15 & 39.48 & Bray and Kurtz II, 1945 \\
\hline Potassium (K), cmol (+) $\mathrm{kg}^{-1}$ & 0.11 & 0.20 & 0.11 & Sumner and Miller, 1996 Ammonium acetate \\
\hline Calcium (Ca), cmol (+) $\mathrm{kg}^{-1}$ & 3.77 & 2.60 & 0.68 & \\
\hline Magnesium $(\mathrm{Mg}), \mathrm{mg} \mathrm{kg}^{-1}$ & 1.14 & 0.69 & 0.35 & \\
\hline Mangenese $(\mathrm{Mn}), \mathrm{mg} \mathrm{kg}^{-1}$ & 0.99 & 0.76 & 0.79 & Reed and Martens 1996 Mehlich-1 (Double acid) \\
\hline Cuprum $(\mathrm{Cu}), \mathrm{mg} \mathrm{kg}^{-1}$ & 70.40 & 89.90 & 111.80 & \\
\hline Zink (Zn), $\mathrm{mg} \mathrm{kg}^{-1}$ & 57.55 & 25.43 & 25.74 & \\
\hline Iron $(\mathrm{Fe}), \mathrm{mg} \mathrm{kg}^{-1}$ & 32.30 & 22.25 & 28.20 & Bertsch and Bloom, 1996 Potassium chloride \\
\hline Alumium (Al), $\mathrm{mg} \mathrm{kg}^{-1}$ & 13.63 & 45.10 & 21.96 & \\
\hline
\end{tabular}

Three soil samples were taken randomly for each soil series for physical analysis which were soil color, soil pH, soil texture, soil bulk density, total porosity and soil moisture. The soil color was compared visually by using Soil Munsell Color Chart. The soil proportion of silt, clay and sand of the soils to reflect the soil texture were determined by using pipette method (Day, 1965) and referred to USDA soil classification triangle for soil type determination. The bulk density of the soils were measured using the core method while pycnometer method was used for soil particle density analysis (Blake and Hartge, 1986). The soil cores were collected and weighed for wet and oven dry before the bulk density of the soil samples were calculated from the ratio of mass of dry soil per unit volume of the core sample after samples were oven-dried at $105^{\circ} \mathrm{C}$ for 
24 hours. The soil moisture content was determined by using gravimetric method where the moisture content was in percent and calculated as the mass of moisture in the soil sample divided by the mass of the dry soil. The total porosity of each soil samples was calculated from bulk density and particle density values by using the following equation (Brady and Weil 2010):-

\section{[1-(bulk density/particle density)] x 100}

Agronomic data measured at tasseling (45 days) were number of leaves per plant, plant height, total root length, root volume, total wet biomass and total dry biomass. The leaf, stem and root were harvested and cleaned before the measurements were taken. The data were analysed using Statistical Analysis Software 9.1.3 (SAS Institute Inc) by using Duncan Multiple Range's Test (DMRT) for mean comparison at $\mathrm{p} \geq 0.05$.

\section{RESULTS AND DISCUSSION}

\subsection{Soil colour of the Rasau, Kuah and Dampar series}

The colour of each soil series was mostly grouped as brown in colour except for Kuah as dark yellowish brown (Table 2). The differences in colour of soil are subjected to several factors such as biological decomposition, chemical reaction and soil parent materials. At upper soil depth, the soil colour is often dark in colour, due to partially decomposed organic matter compared at lower soil depth. Brady and Weil (2010) stated that the amount of proteins or specific minerals present in the soil influenced the soil colour. Yellow or red soil indicates the presence of iron oxides while manganese oxide causes a black colour, glauconite or iron potassium phyllosilicate makes the soil green and calcite can make soil in arid regions appear white. The information on soil colour is an important indicator of the soil conditions in term of soil moisture and mineral content which reflect soil fertility status of the soil for plant growth.

TABLE 2

SOIL COLOUR OF THE RASAU, KUAH AND DAMPAR SOILS AT 0-20cm SOIL DEPTH.

\begin{tabular}{|c|c|c|c|}
\hline Soil series & Soil color chart & Soil color & Image \\
\hline Rasau & $10 \mathrm{YR} 4 / 3$ & Brown & \\
\hline Kuah & $10 \mathrm{YR} 3 / 4$ & Dark yellowish brown & \\
\hline Dampar & 7.5 YR 4/4 & Brown & \\
\hline
\end{tabular}

\subsection{Comparison of soil texture, bulk density, particle density, porosity and soil moisture}

The soil particle analysis showed similar trend on the proportion of sand, silt and clay present in the three marginal soil where sand > silt> clay except for Dampar with silt $>$ clay> sand (Table 3). The Rasau soil contained higher proportion of sand particles followed by Kuah and Dampar whereas Dampar was observed to contain higher proportion of silt and clay as compared with Kuah and Rasau. Overall, Kuah showed intermediate percentage of sand, silt and clay between Rasau and Dampar soils. The different percentage of the soil particle caused the soil texture of the marginal soil to be dissimilar. The soil texture is crucial in terms of soil chemical and physical properties. Fraga et al. (2014) stated that soil texture class of any 
soil type presents its own properties in terms of agricultural applicability and affects the movement and availability of air, nutrients and water in a soil.

The results depicted that Kuah soil series has better soil texture compared with Rasau and Dampar due to the intermediate proportion of sand, silt and clay and was categorised into loam soil texture which could provide good aeration for root growth, drainage and nutrient holding capacity. Furthermore, Rasau soil texture is grouped into loamy sandy as sand particle is predominant as high as $80 \%$ with average $\pm 10 \%$ silt and clay. Therefore, Rasau soil expected to provide good aeration to the plant roots, good for drainage and favourable nutrient uptake with consideration of sufficient soil moisture but disadvantages with high percentage of sand on Rasau soil, the soil likely to have low water retention and nutrient holding capacity. Moreover, this study revealed that Dampar soil texture is clay loam with low in sand percentage (21\%) but intermediate silt and clay percentage around $42 \%$ and $36 \%$, respectively (Table 3). It indicated that Dampar soil has high risk of water logging condition due to poor drainage system even though it has higher proportion of clay which would improve nutrient and water availability. According to Moges et al. (2013) the soil textural fractions varied with land use, while silt, clay and bulk density differed with soil depths but the soil $\mathrm{pH}$ did not show any significant variation across land use types or soil depths.

TABLE 3

THE PROPORTION OF SAND, SILT, CLAY AND SOIL TEXTURE OF THE RASAU, KUAH AND DAMPAR SOIL SERIES.

\begin{tabular}{|c|c|c|c|c|}
\hline Soil series & Sand & Silt & Clay & Texture \\
\hline & \multicolumn{3}{|c|}{$\longrightarrow \%$} & \\
\hline Rasau & $80.30 \mathrm{a}$ & $10.30 \mathrm{c}$ & $9.40 \mathrm{c}$ & Loamy sand \\
\hline Kuah & $52.00 \mathrm{~b}$ & $36.10 \mathrm{~b}$ & $11.86 \mathrm{~b}$ & Loam \\
\hline Dampar & $21.14 \mathrm{c}$ & $42.43 \mathrm{a}$ & $36.43 \mathrm{a}$ & Clay loam \\
\hline
\end{tabular}

Different soil texture of the soils also affected the bulk density, particle density, porosity, and soil moisture (Table 4). The soil with higher bulk density value would have low porosity value and vice versa. The porosity will influence soil water retention including soil moisture, which is related with the availability of oxygen to the plant roots. It was observed that Dampar soils have greater physical properties and capable to retain about $18 \%$ of soil moisture followed by Rasau and Kuah at 13 and $11 \%$, respectively. Rasau and Kuah soils showed similarity in term of bulk density properties as both of the soil contain high sand particle and at the same time there was significant difference in term of soil moisture as generally about $50 \%$ of the soil component are filled with air and water other than organic matter and soil particle. Soil with high sand particle have less total pore space and relatively have high bulk density compared with silt and clay soil. Nunes et al. (2016) claimed that soil densities higher than $1.21 \mathrm{Mg} \mathrm{m}^{-3}$ were limiting for corn root dry matter production in the layer of $0.2-0.3 \mathrm{~m}$ and total of roots dry matter grown in Oxisol soil type that has of high proportion of sand $\left(549 \mathrm{~g} \mathrm{~kg}^{-1}\right)$ and clay $\left(367 \mathrm{~g} \mathrm{~kg}^{-1}\right)$.

TABLE 4

THE BULK DENSITY, PARTICLE DENSITY, POROSITY AND SOIL MOISTURE OF RASAU, KUAH AND DAMPAR SOIL SERIES.

\begin{tabular}{|c|c|c|c|c|}
\hline Soil series & Bulk density & Particle density & Porosity & Soil Moisture \\
\hline & \multicolumn{2}{|c|}{$\mathrm{g} \mathrm{cm}^{-3}=$} & \multicolumn{2}{|c|}{$-\%=$} \\
\hline Rasau & $1.87 \mathrm{a}$ & $2.36 \mathrm{~b}$ & $20.50 \mathrm{~b}$ & $13.51 \mathrm{~b}$ \\
\hline Kuah & $1.86 \mathrm{a}$ & $2.36 \mathrm{~b}$ & $20.93 \mathrm{~b}$ & $11.78 \mathrm{c}$ \\
\hline Dampar & $1.68 \mathrm{~b}$ & $2.40 \mathrm{a}$ & $30.10 \mathrm{a}$ & $18.80 \mathrm{a}$ \\
\hline
\end{tabular}

\subsection{Effects of different levels of $P$ fertilizer on plant and root growth of sweet corn}

The aboveground and root performance of sweet corn grown in three marginal soils were listed in Table 5. After application of $\mathrm{P}$ fertilizer at several rates with ethephon showed that there were significant differences on plant and root growth data among the soils. At zero and $15 \mathrm{~kg} \mathrm{P}_{2} \mathrm{O}_{5} \mathrm{ha}^{-1}$, there were significant differences on root length and total wet and dry biomass weight, respectively, with the exception at zero $\mathrm{P}$ application for total dry biomass weight. Meanwhile at $45 \mathrm{~kg}_{2} \mathrm{O}_{5} \mathrm{ha}^{-1}$, 
only leaf number and total dry biomass weight were significant. Furthermore, both root length and root volume of the sweet corn were observed significant at $100 \% \mathrm{P}$ fertilizer recommendation which is $60 \mathrm{~kg} \mathrm{P}_{2} \mathrm{O}_{5} \mathrm{ha}^{-1}$ but has no effect on leaf number, plant height and total wet and dry biomass among the soil series. The results revealed that application of ethephon with P fertilizer at $45 \mathrm{~kg} \mathrm{P}_{2} \mathrm{O}_{5}$ ha $^{-1}$ affected the leaf number of sweet corn but not the plant height in term of aboveground part grown on the marginal soils which vary physical soil properties. This result concurred with that of the application of 10-40 $\mathrm{kg} \mathrm{P} \mathrm{ha}{ }^{-1}$ that has no significant effect on plant height of common bean grown in clay loam soil (Turuko and Mohammed, 2014). In comparison to root performances the ethephon application shown significant results at all $P$ fertilizer rates but not at $45 \mathrm{~kg} \mathrm{P}_{2} \mathrm{O}_{5} \mathrm{ha}^{-1}$. It revealed that ethephon application together with $\mathrm{P}$ fertilizer at low rate probably has improved the number of leaves of sweet corn grown on deprived Rasau soils texture compared to Kuah and Dampar.

The differences observed on root performance and total biomass weight in this study were probably due to the differences in the soil $\mathrm{pH}$, soil physical and chemical properties and interactions of $\mathrm{P}$ fertilizer with the soil. The $\mathrm{pH}$ of Dampar soil was recorded at 4.77 but 5.19 for both Rasau and Kuah soil series (Table 1). The findings of this study indicated that Dampar soil is more acidic compared with Rasau and Kuah soil series. Thus it was observed that the root growth was significantly affected by the acidic soil $\mathrm{pH}$ condition. $\mathrm{Zu}$ et al. (2014) also indicated that low soil $\mathrm{pH}$ at 3.5 may directly inhibit root development and reduce seedling growth of black pepper (Piper nigrum L.). Furthermore, different soil texture of the marginal soils also influence the root growth as the proportion of sand, silt and clay has effect on soil bulk density which is related in root penetration capability. The bulk density for Rasau, Kuah and Dampar soil series were 1.87, 1.86 and $1.68 \mathrm{~g}$ $\mathrm{cm}^{-3}$, respectively suggested that resistance to root penetration may be increased and thus limit the root growth. Keisuke et al. (2015) recorded a reduction of $50 \%$ in soybean root growth at bulk density values of $1.82 \mathrm{Mg} \mathrm{m}^{-3}$ and $1.75 \mathrm{Mg} \mathrm{m}^{-3}$ for sandy loam and sandy clay loam. Moreover, $\mathrm{P}$ is the nutrient that is most affected by soil $\mathrm{pH}$ but at the same time the effect of $\mathrm{P}$ fertilization may also vary depending on the balance of other nutrients present (Grant et al., 2005). The results showed that at 15 and $45 \mathrm{~kg} \mathrm{P}_{2} \mathrm{O}_{5} \mathrm{ha}^{-1}$ the sweet corn grown in Rasau soil gave higher high total dry biomass compared with Kuah and Dampar soil series. The results could be associated with the soil texture of Rasau that contained the highest proportion of sand which provide better root penetration for nutrient uptake, particularly P. The findings by Mazengia (2011) also reported that $\mathrm{P}$ enhanced root development and increased total dry biomass of maize that was grown in well-drained kaolinitic clayey soils.

TABLE 5

GROWTH PERFORMANCE OF SWEET CORN AT 45 DAYS AFTER PLANTING AT DIFFERENT P LEVELS.

\begin{tabular}{|c|c|c|c|c|c|c|c|}
\hline \multirow{2}{*}{$P$ rates } & \multirow{2}{*}{ Soil series } & \multirow{2}{*}{$\begin{array}{l}\text { Leaf } \\
\text { number }\end{array}$} & \multirow{2}{*}{$\begin{array}{l}\text { Plant } \\
\text { height }\end{array}$} & \multicolumn{2}{|c|}{ Root } & \multicolumn{2}{|c|}{ Total biomass weight } \\
\hline & & & & Length & Volume & Wet & Dry \\
\hline $\mathrm{kg} \mathrm{P}_{2} \mathrm{O}_{5}$ & & & \multicolumn{2}{|c|}{$\longrightarrow \mathrm{cm} \longrightarrow$} & $\mathrm{mL}$ & \multicolumn{2}{|c|}{$\mathrm{g} \longrightarrow$} \\
\hline \multirow{3}{*}{0} & Rasau & $12 \mathrm{a}$ & $117.63 \mathrm{a}$ & $77.00 \mathrm{a}$ & $45.00 \mathrm{a}$ & $232.50 \mathrm{a}$ & $74.39 \mathrm{a}$ \\
\hline & Kuah & $12 \mathrm{a}$ & $106.75 \mathrm{a}$ & $65.25 \mathrm{ab}$ & $53.75 \mathrm{a}$ & $195.50 \mathrm{ab}$ & $68.03 \mathrm{a}$ \\
\hline & Dampar & $11 \mathrm{a}$ & $107.50 \mathrm{a}$ & $42.50 \mathrm{~b}$ & $38.75 \mathrm{a}$ & $176.75 \mathrm{~b}$ & $66.89 \mathrm{a}$ \\
\hline & & n.s & n.s & $* *$ & n.s & $* *$ & n.s \\
\hline \multirow{4}{*}{15} & Rasau & $11 \mathrm{a}$ & $118.88 \mathrm{a}$ & $86.13 \mathrm{a}$ & $50.00 \mathrm{a}$ & $238.00 \mathrm{a}$ & $74.50 \mathrm{a}$ \\
\hline & Kuah & $12 \mathrm{a}$ & $106.50 \mathrm{a}$ & $72.00 \mathrm{ab}$ & $52.50 \mathrm{a}$ & $198.50 \mathrm{~b}$ & $66.92 \mathrm{~b}$ \\
\hline & Dampar & $11 \mathrm{a}$ & $97.38 \mathrm{a}$ & $38.00 \mathrm{~b}$ & $43.25 \mathrm{a}$ & $164.25 \mathrm{~b}$ & $63.03 \mathrm{~b}$ \\
\hline & & n.s & n.s & $* *$ & n.s & $* *$ & $* *$ \\
\hline \multirow{3}{*}{45} & Rasau & $13 \mathrm{a}$ & $111.88 \mathrm{a}$ & $89.13 \mathrm{a}$ & $37.50 \mathrm{a}$ & $207.75 \mathrm{a}$ & $70.35 \mathrm{a}$ \\
\hline & Kuah & $12 \mathrm{ab}$ & $100.25 \mathrm{a}$ & $74.25 \mathrm{a}$ & $46.50 \mathrm{a}$ & $173.50 \mathrm{a}$ & $62.96 \mathrm{~b}$ \\
\hline & Dampar & $11 \mathrm{~b}$ & $95.00 \mathrm{a}$ & $68.15 \mathrm{a}$ & $43.75 \mathrm{a}$ & $162.50 \mathrm{a}$ & $62.20 \mathrm{~b}$ \\
\hline & & $* *$ & $\mathrm{~ns}$ & $\mathrm{~ns}$ & $\mathrm{~ns}$ & $\mathrm{~ns}$ & $* *$ \\
\hline \multirow{4}{*}{60} & Rasau & $12 \mathrm{a}$ & $104.00 \mathrm{a}$ & $53.50 \mathrm{a}$ & $30.00 \mathrm{~b}$ & $202.75 \mathrm{a}$ & $69.67 \mathrm{a}$ \\
\hline & Kuah & $12 \mathrm{a}$ & $103.50 \mathrm{a}$ & $63.43 \mathrm{a}$ & $50.00 \mathrm{a}$ & $201.50 \mathrm{a}$ & $68.91 \mathrm{a}$ \\
\hline & Dampar & $12 \mathrm{a}$ & $99.88 \mathrm{a}$ & $33.38 \mathrm{~b}$ & $42.50 \mathrm{ab}$ & $192.75 \mathrm{a}$ & $59.64 \mathrm{a}$ \\
\hline & & n.s & n.s & $* *$ & $* *$ & n.s & n.s \\
\hline
\end{tabular}




\section{CONCLUSION}

The soil color of Kuah and Dampar were recorded as brown and dark yellowish brown for Kuah indicated these soils were less in organic matter with carbon content range from $0.06-0.08 \%$. The results depicted that the marginal soil namely Rasau soil series has poorer soil texture as compared with Kuah and Dampar but with application of P fertilizer at low rates and ethephon, number of leaves and roots performances were improved for sweet corn. The growth performance of sweet corn were significant in term of number of leaves, root length and root volume including total biomass weight wet and dry but no effect of ethephon was recorded on plant height. As conclusion, in order to improve the potential of these three marginal soils for plant and root growth, application of $\mathrm{P}$ fertilizer with ethephon as low as $15 \mathrm{~kg} \mathrm{P}_{2} \mathrm{O}_{5}$ ha $^{-1}$ up to $45 \mathrm{~kg}_{2} \mathrm{O}_{5}$ ha $^{-1}$ for sweet corn is certainly an important aspect to consider.

\section{ACKNOWLEDGEMENTS}

The authors would like to acknowledge University Malaysia Perlis, University Putra Malaysia and Malaysian Agricultural Research and Development Institute for the technical support and Ministry of Higher Education of Malaysia for financial support under Fundamental Research Grant Scheme (FGRS).

\section{REFERENCES}

[1] Adnan, D. Mavinic and F. Koch, "Pilot-scale study of phosphorus recovery through struvite crystallization - examining the process feasibility", Journal of Environmental Engineering and Science, vol. 2, no. 5, pp. 315-324, 2003.

[2] J. Nunes, E. Bonfim-Silva and T. Silva, "Bulk density and water tensions in the soil on corn root production", Revista Brasileira de Engenharia Agrícola e Ambiental, vol. 20, no. 4, pp. 357-363, 2016.

[3] N. Brady and R. Weil, The nature and properties of soils, 3rd ed. Upper Saddle River, N.J.: Pearson Prentice Hall, 2010.

[4] R. Bray and L. Kurtz, "Determination of total, organic and available form of Phosphorus in soil", Soil Science, vol. 59, no. 1, pp. 3946, 1945.

[5] P. Day, Particle Fractionation and particle-size analysis. In C.A Black (ed) Methods of soil analysis, 1st ed. Madison: American Soc. Agronomy, 1965, pp. 545-567.

[6] H. Fraga, A. Malheiro, J. Moutinho-Pereira, R. Cardoso, P. Soares, J. Cancela, J. Pinto and J. Santos, "Integrated Analysis of Climate, Soil, Topography and Vegetative Growth in Iberian Viticultural Regions", PLoS ONE, vol. 9, no. 9, pp. 1-14, 2014.

[7] C. Grant, S. Bittman, M. Montreal, C. Plenchette and C. Morel, "Soil and fertilizer phosphorus: Effects on plant P supply and mycorrhizal development", Canadian Journal of Plant Science, vol. 85, no. 1, pp. 3-14, 2005.

[8] M. Keisuke Sato, H. Veras de Lima, P. Oliveira and S. Rodrigues, "Critical soil bulk density for soybean growth in Oxisols", International Agrophysics, vol. 29, no. 4, pp. 441-447, 2015.

[9] W. Mazengia, "Effects of methods and rates of phosphorus fertilizer application and planting methods on yield and related traits of maize (Zea mays L.) on soil of Hawassa Area", Innov. Syst. Design Engin, vol. 2, no. 4, pp. 315-336, 2011.

[10] A. Moges, M. Dagnachew and F. Yimer, "Land Use Effects on Soil Quality Indicators: A Case Study of Abo-Wonsho Southern Ethiopia", Applied and Environmental Soil Science, vol. 2013, pp. 1-9, 2013.

[11] J. Shamsuddin and A. Markus, "Charge properties of soils in Malaysia dominated by kaolinite, gibbsite, goethite and hematite", Bulletin of the Geological Society of Malaysia, vol. 54, pp. 27-31, 2008.

[12] H. Yang, X. Zhang, R. Gaxiola, G. Xu, W. Peer and A. Murphy, "Over-expression of the Arabidopsis proton-pyrophosphatase AVP1 enhances transplant survival, root mass, and fruit development under limiting phosphorus conditions", Journal of Experimental Botany, vol. 65, no. 12, pp. 3045-3053, 2014.

[13] C. Zu, Z. Li, J. Yang, H. Yu, Y. Sun, H. Tang, R. Yost and H. Wu, "Acid Soil Is Associated with Reduced Yield, Root Growth and Nutrient Uptake in Black Pepper (Piper nigrum L.)", Agricultural Sciences, vol. 05, no. 05, pp. 466-473, 2014.

[14] C. Misheck and C. Fanuel, "Effect of ethephon and planting density on lodged plant percentage and crop yield in maize (Zea mays L.)", African Journal of Plant Science, vol. 8, no. 2, pp. 113-117, 2014.

[15] J. Postma and J. Lynch, "Root Cortical Aerenchyma Enhances the Growth of Maize on Soils with Suboptimal Availability of Nitrogen, Phosphorus, and Potassium", Plant Physiology, vol. 156, no. 3, pp. 1190-1201, 2011.

[16] G. Blake and K. Hartge, "Bulk density In Klute A. Methods of Soil Analysis 2d ed., pt. 1; Physical and Mineralogical Methods", Soil Science, vol. 146, no. 2, pp. 363-375, 1988.

[17] M. Bhat, M. Mir, N. Khan, N. Lone, K. Bhat and S. Razvi, "The role of Ethrel in plant growth and development under different environmental conditions", International Journal of Current Research, vol. 4, pp. 4-13, 2010.

[18] M. Sumner and W. Miller, Cation exchange capacity, and exchange coefficients. In: D.L Sparks Methods of soil analysis Part 2: Chemical properties, 3rd ed. Madison Wisconsin: Soil Science Society of America, 1986, pp. 1201-1230.

[19] S. Reed and D. Martens, Cooper and Zinc. In D.L Sparks Methods of soil analysis Part 2: Chemical Properties, 3rd ed. Madison, Wisconsin: Soil Science Society of America, 1996, pp. 703-722.

[20] P. Bertsch and P. Bloom, Aluminium. In D.L Sparks. Methods of soil analysis. Part 2: Chemical properties, 3rd ed. Madison, Wisconsin: Soil Science Society of America, 1996, pp. 517-550. 
[21] M. Turuko and A. Mohammad, "Effect of Different Phosphorus Fertilizer Rates on Growth, Dry Matter Yield and Yield Components of Common Bean (Phaseolus vulgaris L.)", World Journal of Agricultural Research, vol. 2, no. 3, pp. 88-92, 2014.

[22] A. Wulan and S. Prijono, "Assessment of Infiltration Rate under Different Drylands Types in Unter-Iwes Subdistrict Sumbawa Besar, Indonesia", Journal of Natural Sciences Research, vol. 3, no. 10, pp. 71-76, 2013.

[23] T. Souza, P. Magalhães, E. Castro, V. Duarte and A. Lavinsky, "Corn root morphoanatomy at different development stages and yield under water stress", Pesquisa Agropecuária Brasileira, vol. 51, no. 4, pp. 330-339, 2016. 